\title{
Influence of Fibre Length on Properties of Glass- Fibre Reinforced Bark Particleboards
}

\section{Utjecaj duljine vlakana na svojstva iverice od kore ojačane staklenim vlaknima}

Preliminary paper $\bullet$ Prethodno priopćenje

Received-prispjelo: 9. 10. 2019.

Accepted-prihvaćeno: 15. 7. 2020.

UDK: $630 * 861.232 ; 630 * 892.453$

https://doi.org/10.5552/drvind.2020.1948
(C) 2020 by the author(s). Licensee Faculty of Forestry, University of Zagreb. This article is an open access article distributed under the terms and conditions of the Creative Commons Attribution (CC BY 4.0) license.

\begin{abstract}
This study was carried out to assess the feasibility of glass fibres of various lengths (12 mm, 18 $\mathrm{mm}, 24 \mathrm{~mm}$ and $30 \mathrm{~mm}$ ) as reinforcement on the mechanical performance of bark particleboards intended for thermal insulation. To evaluate their efficiency, the results of fibre reinforced particleboards at mass of $3 w t \%$ concentration were compared with plain bark based boards. Thermal, physical and mechanical properties (modulus of rupture, modulus of elasticity and internal bond) were determined on unreinforced and reinforced specimens. In general, the results of the thermal conductivity measurements indicated that the bark panels could potentially be used as feedstock for thermal insulation panels. However, the glass fibres lengths had a direct adverse effect on the mechanical behaviour of the bark particleboard, instead of providing synergistic reinforcement. Furthermore, the static bending properties, mainly the modulus of rupture, gradually decreased with increasing lengths of glass fibre.
\end{abstract}

Keywords: utilization of bark; bio-based insulation panel; poplar bark

SAŽETAK • Istraživanje je provedeno kako bi se procijenila mogućnost uporabe staklenih vlakana različitih duljina (12; 18; 24 i 30 mm) kao materijala za ojačanje iverica proizvedenih od kore i namijenjenih toplinskoj izolaciji te kako bi se istražio utjecaj tih vlakana na mehanička svojstva iverica. Da bi se procijenio utjecaj staklenih vlakana, uspoređena su svojstva iverica ojačanih staklenim vlaknima masenog udjela vlakana od $3 \%$ i iverica napravljenih od kore, bez ojačanja staklenim vlaknima. Uspoređena su toplinska, fizička i mehanička svojstva (modul loma, modul elastičnosti $i$ međuslojna čvrstoća) uzoraka ploča iverica s ojačanjem staklenim vlaknima $i$ bez ojačanja. U osnovi, rezultati mjerenja toplinske vodljivosti pokazali su da bi se ploče od kore mogle potencijalno upotrebljavati za toplinsku izolaciju. Međutim, duljina staklenih vlakana imala je izravan nepovoljan utjecaj na mehanička svojstva iverica od kore. Nadalje, svojstva statičkog savijanja, uglavnom modul loma, postupno su se smanjivala s povećanjem duljine staklenih vlakana.

Ključne riječi: uporaba kore; izolacijske ploče na prirodnoj bazi; kora od topolovine

\footnotetext{
${ }^{1}$ Authors are researchers at University of Sopron, Faculty of Technology, Wood Science and Art, Innovation Center, Sopron, Hungary.
} 


\section{INTRODUCTION}

\section{UVOD}

According to the European Union, the building sector is responsible for consuming $40 \%$ of the total energy in Europe. Therefore, ways of improving thermal efficiency and decreasing greenhouse gases emissions, such as thermal insulation of building envelopes, is one of the most crucial methods to maximize the energy savings of a building during winter heating and summer air-conditioning (Schiavoni et al., 2016).

Bio-based thermal insulation materials cover a variety of natural fibre resources such as cellulose (Hurtado et al., 2016), bast fibres such as hemp and flax (Latif et al., 2014; Nguyen et al. 2016), cotton stalk (Zhou et al., 2010) coconut husk or sugarcane bagasse (Panyakaew and Fotios, 2011), rice straw (Wei et al., 2015), sunflower stalks (Mati-Baouche et al., 2014) or other crop by-products (Palumbo et al., 2015), wood shavings (Sekino, 2016), textile waste from plant fibres (Lacoste et al., 2018), and agglomerated cork (Barreca and Fichera, 2016) etc.

Bark (as a lignocellulosic residue), is mainly burned as a fuel for heat energy in wood mills. However, recent research efforts consider the use of bark as raw material in the production of particleboard (Yemele et al., 2008), wood-plastic composites (Yemele et al., 2010), and as thermal insulation material in the form of polyurethane foam (D'Souza et al., 2016) or rigid panels (Kain et al., 2016; Pásztory et al., 2017).

One of the essential limitations on the exploitation of bark particles in wood industry is the resulting weakness of the mechanical properties of the manufactured wood-based panels or composites. A potential solution to overcome this issue could be the reinforcement of bark particle boards with common synthetic fibres such as glass, carbon, basalt and aramid. Glass fibres were examined as reinforcing filaments in cement and concrete composites (Kizilkanat et al., 2015; Arslan, 2016) and wood-plastic composites (Zolfagari et al., 2015). The flexural strength and the compressive strength of the concrete can be improved by adding glass fibre to the matrix (Majumdar and Nurse, 1974;
İskender and Karasu, 2018). The flexural properties of solid and laminated wood beams, plywood and particleboards were also investigated by overlaying glass fibre on the surface (Smulski and Ifju, 1987).

The objectives of this research were to i) examine the effect of the length of glass fibres on the thermal, physical and mechanical performance of glass fibres reinforced bark particleboards, ii) determine the most suitable critical length of glass fibres reinforcement and iii) investigate their market potential as thermal insulation panels.

\section{MATERIALS AND METHODS 2. MATERIJALI I METODE}

\subsection{Materials}

\subsection{Materijali}

The whole bark samples (inner and outer bark) used in this research were directly collected from the debarking units processing harvested poplar (Populus euramericana $c v$. Pannónia) logs with a wide diameter range, which were stored in a local sawmill in the area of Sopron, Hungary. The E-glass fibre roving used for this study was supplied by PD Tatneft-Alabuga Fiberglass LLC (Yelabuga, Russia) (Table 1). The lengths of $12 \mathrm{~mm}$ (GF_12), $18 \mathrm{~mm}$ (GF 18), $24 \mathrm{~mm}$ (GF 24) and $30 \mathrm{~mm}$ (GF_30) were manually cut from the fibreglass roving cylindrical packages (Figure 1) similarly as Tsalagkas et al. (2019). The main properties of the glass fibres and their lengths used in this work are given in Table 1 and Figure 1, respectively. The commercial UF resin and hardener used in this work was purchased from DUKOL Ostrava s.r.o. The resin properties at $20{ }^{\circ} \mathrm{C}$ were: solid content $67.65 \%$; pH value 8.8; dynamic viscosity $500 \mathrm{mPa} \cdot \mathrm{s}$; and Ford cup viscosity 84 seconds.

\subsection{Particleboard manufacturing \\ 2.2. Proizvodnja iverice}

Initially, bark slices of various thicknesses (15-30 $\mathrm{mm})$, consisting of inner and outer bark, were collected and dried below $20 \%$ in a chamber. Consecutively, the inner and outer bark were cut into small pieces and

Table 1 Main properties of glass fibres (data was provided by the manufacturer of glass fibres)

Tablica 1. Osnovna svojstva staklenih vlakana (podatci su dobiveni od proizvođača vlakana)

\begin{tabular}{|c|c|c|c|c|c|}
\hline $\begin{array}{c}\text { Product code } \\
\text { Sifra proizvoda }\end{array}$ & $\begin{array}{c}\text { Type of fibres } \\
\text { Vrsta vlakana }\end{array}$ & $\begin{array}{c}\text { Filament diameter, mm } \\
\text { Promjer filamenta, mm }\end{array}$ & $\begin{array}{c}\text { Linear density, tex } \\
\text { Linearna gustoća, tex }\end{array}$ & MC, \% & $\begin{array}{c}\text { Breaking strength, gf/tex } \\
\text { Prekidna čvrstoća, gf/tex }\end{array}$ \\
\hline EC 14-300-350 & $\begin{array}{c}\text { E-glass } \\
\text { Silane modified }\end{array}$ & $14.0 \pm 1.5$ & $300 \pm 15$ & $<0.20$ & $>45$ \\
\hline
\end{tabular}
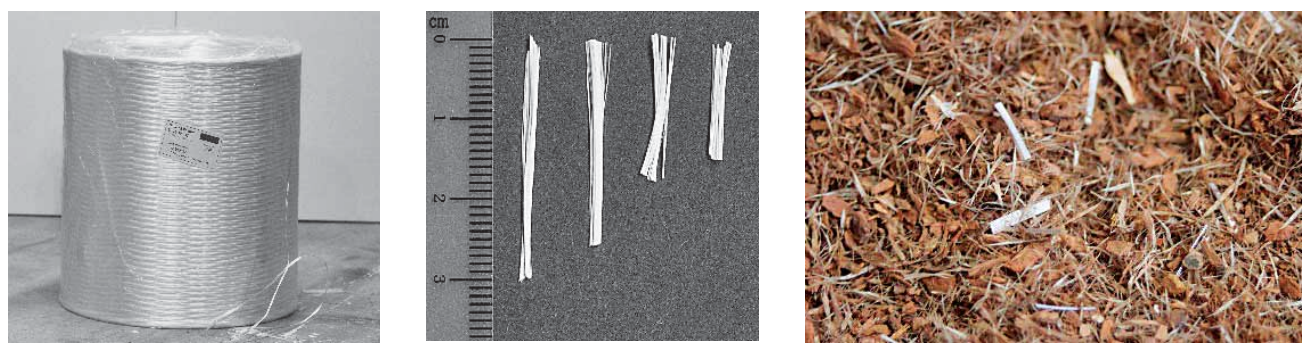

Figure 1 Glass fibres used in this study (a) roving, (b) fibres lengths and (c) mixed with bark particles

Slika 1. Staklena vlakna primijenjena u istraživanju: a) namotana, b) vlakna različite duljine, c) pomiješana s iverjem kore 
chipped into particles using a hammer mill equipped with $8 \mathrm{~mm}$ screening holes. The granulated bark particles ranged from $0.5 \mathrm{~mm}$ to $8 \mathrm{~mm}$ fractions and were used as raw material for the manufacturing of bark panels. The moisture content of the bark particles was adjusted to 6 to $9 \%$ before further processing. The randomly oriented, chopped glass fibres of the prepared length were placed in a laboratory blender and homogenized with the bark particles for five minutes, before pressing. A mass of $4 \%$ urea formaldehyde (UF) adhesive was sprayed on and was mixed to the mixture of the bark particles and glass fibres. The adhesive contains $35 \%$ of aqueous solution of ammonium sulphate $\left(\mathrm{NH}_{4}\right)_{2} \mathrm{SO}_{4}$ as catalyst. The glued mixtures were immediately manually layered and formed in a wooden frame into a mat. Thereafter, the frame was removed, and the mats were pre-pressed by hand to compact the materials without heat transfer.

Next, the mats were transferred to a single-opening hydraulic hot press machine (Siempelkamp). The pressing temperature was set at $180^{\circ} \mathrm{C}$ with a pressing time of 18 seconds per millimetre of thickness. The initial press pressure was $2.86 \mathrm{MPa}$, which was reduced after 120 seconds to $2 \mathrm{MPa}$, and after $240 \mathrm{sec}-$ onds to $1.15 \mathrm{MPa}$ to decrease the risk of panel damage by vapour. Single-layered boards with dimensions of $500 \mathrm{~mm} \times 500 \mathrm{~mm} \times 20 \mathrm{~mm}$ with a target density of $350 \mathrm{~kg} / \mathrm{m}^{3}$ were produced.

\subsection{Characterization}

\subsection{Karakterizacija}

All the composite boards were kept at $20^{\circ} \mathrm{C}$ and $65 \%$ relative humidity, until equilibrium moisture content (EMC) was achieved, prior to experimental measurements. All these boards were cut and trimmed into various test specimens.

Apparent density $\rho$ at 9.5-10.2\% moisture content was measured on the same samples used for the mechanical tests, as the average of at least fifteen specimens. The mechanical bending test was done according to the standard (EN 323:1993). Dimensional stability of the specimens from thickness swelling (TS) and water absorption (WA) were calculated according to European Standard EN 317:1993.

Thermal conductivity was measured across the thickness of the composite boards $(500 \mathrm{~mm} \times 500 \mathrm{~mm}$ $\times 20 \mathrm{~mm}$ ) with a heat flow meter using a guarded hotplate method. The thermal conductivity measuring equipment was designed and assembled at the Technical University of Budapest. The measurement started when the steady state was achieved, i.e. when the fluctuation of the last fifty per minute measurements was under $0.002 \mathrm{~W} / \mathrm{mK}$.

The bending strength $(M O R)$ and modulus of elasticity $(M O E)$ of bark composite boards were measured using a universal testing machine Instron 5506 (static three-point bending), in compliance with the applicable European Standard EN 310:1993 at a crosshead speed of $8 \mathrm{~mm} / \mathrm{min}$. The tensile strength perpendicular to the surface (internal bond, $I B$ ) was determined by using $50 \mathrm{~mm} \times 50 \mathrm{~mm}$ specimens from each panel according to EN 319:1993, at a speed of $0.8 \mathrm{~mm} / \mathrm{min}$.

\subsection{Statistical analysis}

2.4. Statistička analiza

The analysis of variance (ANOVA) was applied using Statistica13 software (TIBCO Software Inc., USA) to statistically evaluate the influence of the length of glass fibres on the thermal, mechanical and dimensional stability of the glass fibre reinforced bark boards produced in the current study. All data were checked for normality (Shapiro-Wilk test) and homogeneity of variance (Levene's test), at a $5 \%$ significance level. Extreme values that did not fit the homogeneity or normality were excluded from subsequent analyses. Post hoc tests were conducted with Tukey's HSD test method at $5 \%$ significance level.

\section{RESULTS AND DISCUSSION}

\section{REZULTATI I RASPRAVA}

Table 2 presents the mean values of the physical, thermal and mechanical properties of the bark particleboards reinforced with various glass fibre lengths ranging from $12 \mathrm{~mm}$ to $30 \mathrm{~mm}$ with a $6 \mathrm{~mm}$ interval. The mean density of the unreinforced and glass fibre reinforced bark particleboards fluctuated from 373.21 to $387.57 \mathrm{~kg} / \mathrm{cm}^{3}$, while the moisture content was estimated between $9.58 \%$ and $10.18 \%$. The dimensional stability (TS \% and WA \%) was found not to be statistically different among the boards, indicating that glass fibres had no influence on these properties. In addition, the thermal conductivity of the boards was shown to be similar, in the area of $0.074-0.078 \mathrm{~W} / \mathrm{m} \cdot \mathrm{K}$, among all the panels made of bark-glass fibre composite boards, whilst the thermal conductivity of the bark particleboards was calculated as $0.079 \mathrm{~W} / \mathrm{m} \cdot \mathrm{K}$. Compared with other bio-based natural insulation materials, the obtained values were higher or contiguous to other wood-based panels (Pásztory et al., 2017), yet in a similar range. It is evident that the addition of glass fibres, with their lengths varying from $12 \mathrm{~mm}$ up to 30 $\mathrm{mm}$, had a negative effect instead of a synergistic one on the static bending properties of bark particleboards. The control boards had the highest MOR and MOE values compared to the reinforced bark boards. Further, the $M O R$ and $M O E$ decreased with increasing the fibre length from $12 \mathrm{~mm}$ to $30 \mathrm{~mm}$. The boards reinforced with a glass fibre length of $12 \mathrm{~mm}$ indicated the best mechanical performance among the fibre lengths tested. For specimens with a $12 \mathrm{~mm}$ glass fibre length, the MOR of the panels decreased by $28.17 \%$ compared to control specimens. Furthermore, the MOR of $18 \mathrm{~mm}$ length panels additionally decreased by $17.65 \%$ (related to $12 \mathrm{~mm}$ ), the MOR of $24 \mathrm{~mm}$ fibre length panels further decreased by $10.71 \%$ (in relation to $18 \mathrm{~mm}$ ) and the MOR of $30 \mathrm{~mm}$ glass fibres reinforced again decreased by $12.00 \%$ compared to $24 \mathrm{~mm}$ long fibres. Accordingly, the $M O E$ value gradually decreased from $0.24 \mathrm{GPa}$ to $0.19 \mathrm{GPa}$ with fibres $12 \mathrm{~mm}$ long and then remained constant with longer fibre lengths.

However, it has to be noted that difficulties in workability or flocculation of fibres during mixing were observed with increasing fibre lengths, at the suggested 
Table 2 Physical, thermal and mechanical properties of the proposed glass fibre reinforced bark particleboards. Numbers in brackets represent standard deviation values.

Tablica 2. Fizička, toplinska i mehanička svojstva uzoraka iverica od kore drva ojačanih staklenim vlaknima (brojevi u zagradama vrijednosti su standardne devijacije)

\begin{tabular}{|c|c|c|c|c|c|}
\hline Physical properties / Fizička svojstva & Control & GF_12 & GF_18 & GF_24 & GF_30 \\
\hline$\rho, \mathrm{kg} / \mathrm{m}^{3}$ & $\begin{array}{c}387.57 \\
(14.24) \\
\end{array}$ & $\begin{array}{c}376.89 \\
(19.46) \\
\end{array}$ & $\begin{array}{l}375.60 \\
(14.82)\end{array}$ & $\begin{array}{l}377.63 \\
(12.47)\end{array}$ & $\begin{array}{l}373.21 \\
(15.80)\end{array}$ \\
\hline$M C, \%$ & $\begin{array}{c}9.73 \\
( \pm 0.39) \\
\end{array}$ & $\begin{array}{c}9.66 \\
( \pm 0.84)\end{array}$ & $\begin{array}{c}10.18 \\
( \pm 0.09)\end{array}$ & $\begin{array}{c}9.86 \\
( \pm 0.27) \\
\end{array}$ & $\begin{array}{c}9.58 \\
( \pm 0.28)\end{array}$ \\
\hline$W A, \%(24 \mathrm{~h})$ & $\begin{array}{l}182.47^{a^{*}} \\
(25.73)\end{array}$ & $\begin{array}{l}193.23^{a} \\
(28.0)\end{array}$ & $\begin{array}{l}173.87^{a} \\
(16.91)\end{array}$ & $\begin{array}{l}177.54^{\mathrm{a}} \\
(18.29)\end{array}$ & $\begin{array}{l}190.94^{\mathrm{a}} \\
(26.26)\end{array}$ \\
\hline$T S, \%(24 \mathrm{~h})$ & $\begin{array}{c}8.15^{\mathrm{a}} \\
(0.99) \\
\end{array}$ & $\begin{array}{c}8.88^{\mathrm{a}} \\
(1.12) \\
\end{array}$ & $\begin{array}{c}9.18^{\mathrm{a}} \\
(0.80) \\
\end{array}$ & $\begin{array}{c}9.14^{\mathrm{a}} \\
(1.15) \\
\end{array}$ & $\begin{array}{c}9.28^{\mathrm{a}} \\
(0.88) \\
\end{array}$ \\
\hline \multicolumn{6}{|l|}{ Thermal properties / Toplinska svojstva } \\
\hline$\lambda, \mathrm{W} / \mathrm{mK}$ & $\begin{array}{c}0.079 \\
(0.003)\end{array}$ & $\begin{array}{c}0.074 \\
(0.007)\end{array}$ & $\begin{array}{c}0.075 \\
(0.002)\end{array}$ & $\begin{array}{c}0.078 \\
(0.004)\end{array}$ & $\begin{array}{c}0.076 \\
(0.002)\end{array}$ \\
\hline \multicolumn{6}{|c|}{ Mechanical properties / Mehanička svojstva } \\
\hline$M O R, \mathrm{MPa}$ & $\begin{array}{c}1.42^{\mathrm{c}} \\
(0.24)\end{array}$ & $\begin{array}{c}1.02^{\mathrm{b}} \\
(0.21)\end{array}$ & $\begin{array}{l}0.84^{\mathrm{a}, \mathrm{b}} \\
(0.18)\end{array}$ & $\begin{array}{c}0.75^{\mathrm{a}} \\
(0.22)\end{array}$ & $\begin{array}{c}0.66^{\mathrm{a}} \\
(0.19)\end{array}$ \\
\hline$M O E, \mathrm{GPa}$ & $\begin{array}{c}0.24^{c} \\
(0.04)\end{array}$ & $\begin{array}{c}0.19^{\mathrm{b}} \\
(0.03)\end{array}$ & $\begin{array}{c}0.15^{\mathrm{a}} \\
(0.02)\end{array}$ & $\begin{array}{c}0.15^{\mathrm{a}} \\
(0.02) \\
\end{array}$ & $\begin{array}{c}0.15^{\mathrm{a}} \\
(0.03)\end{array}$ \\
\hline$I B, \mathrm{~N} / \mathrm{mm}^{2}$ & $\begin{array}{c}0.11^{\mathrm{a}, \mathrm{b}} \\
( \pm 0.01)\end{array}$ & $\begin{array}{c}0.13^{\mathrm{b}} \\
( \pm 0.02)\end{array}$ & $\begin{array}{c}0.10^{\mathrm{a}, \mathrm{b}} \\
( \pm 0.03)\end{array}$ & $\begin{array}{c}0.09^{\mathrm{a}} \\
( \pm 0.01)\end{array}$ & $\begin{array}{c}0.12^{\mathrm{a}, \mathrm{b}} \\
( \pm 0.03)\end{array}$ \\
\hline
\end{tabular}

* Mean specimen values and standard deviations (expressed in brackets), obtained in different groups. The same letters indicate statistically insignificant differences $(p>0.05)$.

* Srednje vrijednosti i standardne devijacije (prikazane u zagradama) dobivene u različitim skupinama. Ista slova znače da među označenim vrijednostima nema statistički značajne razlike $(p>0,05)$.

$3 w t \%$ concentration. A possible explanation for the decreasing flexural rupture could be a combination of several factors, such as the shear stresses distribution, the air voids in the panel material and the overlapping degree of the reinforced bark particleboards with longer glass fibre lengths. Furthermore, statistically, the IB values were not significantly affected by the reinforcement, demonstrating that the glass fibres had no interaction with the urea-formaldehyde bonded bark particles, therefore indicating no cohesion between the glass fibres and bark particles. This assumption was made because the glass fibres area on the breaking surface appears in higher ratio than the ratio of glass fibres in the volume. Consequently, the connection between the fibres and the urea formaldehyde glued bark particles was weaker than the bonding between glued bark particles. The bonding connection between urea formaldehyde resin and glass fibre was investigated by Sharma et al. (2015) from different mechanical aspects, but the positive effect of the glass fibre was not apparent.

\section{CONCLUSIONS}

\section{ZAKLJUČAK}

Glass fibre reinforced bark particleboards were evaluated as thermal insulation panels. The thermal conductivity investigation demonstrated the viability of the proposed boards as insulation panels. However, test results showed a negative influence especially on the bending strength $(M O R)$ of the reinforced bark particleboards using the various glass fibre lengths. As the glass fibre length became longer, the flexural strength of reinforced bark particleboards reduced significantly. Therefore, the glass fibre $12 \mathrm{~mm}$ long demonstrated the best perfor- mance among the tested specimens. In addition, the internal bond strength of the reinforced specimens was not statistically different compared to control bark particleboards, indicating no cohesion between the glass fibres and the bark particles bonded with urea formaldehyde adhesive. Therefore, this study will be focused on i) the use of shorter glass fibre lengths such as $6 \mathrm{~mm}$ and $3 \mathrm{~mm}$ and ii) the improvement of interfacial interaction between the bark particles and glass fibres through surface modification methods, or by examining other adhesives.

\section{Acknowledgements - Zahvala}

The work was carried out as part of the "Sustainable Raw Material Management Thematic Network RING 2017', EFOP-3.6.2-16-2017-00010 project in the framework of the Széchenyi 2020 Program. This project is supported by the European Union, co-financed by the European Social Fund.

\section{REFERENCES}

5. LITERATURA

1. Arslan, M. E., 2016: Effects of basalt and glass chopped fibers addition on fracture energy and mechanical properties of ordinary concrete: CMOD measurement. Construction and Building Materials, 114: 383-391. http://dx.doi.org/10.1016/j.conbuildmat.2016.03.176.

2. Barreca, F.; Fichera, C. R., 2016: Thermal insulation performance assessment of agglomerated cork boards. Wood and Fiber Science, 48 (2): 1-8.

3. Tsalagkas, D.; Börcsök, Z.; Pásztory, Z.; 2019: Modulus of Elasticity Assessment of Glass-Fibre Reinforced Bark-Based Panels by Acoustic Resonance Vibration Non-Destructive Test, IOP Conf. Series: Earth and Environmental Science 307, 012004.

http://dx.doi.org/10.1088/1755-1315/307/1/012004. 
4. D’Souza, J.; Wong, S. Z.; Camargo, R.; Yan, N., 2016: Solvolytic liquefaction of bark: understanding the role of polyhydric alcohols and organic solvents on polyol characteristics. ACS Sustainable Chemical Engineering, 4 (3): 851-861.

http://dx.doi.org/10.1021/acssuschemeng.5b00908.

5. Hurtado, P. L.; Rouilly, A.; Vandenbossche, V.; Raynaud, C., 2016: A review on the properties of cellulose fibre insulation. Building and Environment, 96: 170-177. http://dx.doi.org/10.1016/j.buildenv.2015.09.031.

6. İskender, M.; Karasu, B., 2018: Glass Fibre Reinforced Concrete (GFRC). El-Cezerî Journal of Science and Engineering, 5 (1): 136-162. http://dx.doi.org/10.31202/ecjse.371950.

7. Kain, G.; Lienbacher, B.; Barbu, M. C.; Plank, B.; Richter, K.; Petutschnigg, A., 2016: Evaluation of relationships between particle orientation and thermal conductivity in bark insulation board by means of CT and discrete modeling. Case Studies in Non-destruct Test Evaluation Part B, 6: 21-29. http://dx.doi.org/10.1016/j.csndt.2016.03.002.

8. Kizilkanat, A. B.; Kabay, N.; Akyüncü, V.; Chowdhury, S.; Akça, A. H., 2015: Mechanical properties and fracture behavior of basalt and glass fiber reinforced concrete: An experimental study. Construction and Building Materials, 100: 218-224.

http://dx.doi.org/10.1016/j.conbuildmat.2015.10.006.

9. Lacoste, C.; El Hage, R.; Bergeret, A.; Corn, S.; Lacroix, P., 2018: Sodium alginate adhesives as binders in wood fibers/textile waste fibers biocomposites for building insulation. Carbohydrate Polymers, 184: 1-8. http://dx.doi.org/10.1016/j.carbpol.2017.12.019.

10. Latif, E.; Tucker, S.; Ciupala, M. A.; Wijeyesekera, D. C.; Newport, D., 2014: Hygric properties of hemp bioinsulations with differing compositions. Construction and Building Materials, 66: 702-711. http://dx.doi.org/10.1016/j.conbuildmat.2014.06.021.

11. Majumdar, A. J.; Nurse, R. W., 1974: Glass Fibre Reinforced Cement. Materials Science and Engineering, 15: 107-127.

12. Mati-Baouche, N.; De Baynast, H.; Lebert, A.; Sun, S.; Lopez-Mingo, C. J. S.; Leclaire, P.; Michaud, P., 2014: Mechanical, thermal and acoustical characterizations of an insulating bio-based composite made from sunflower stalks particles and chitosan. Industrial Crops and Products, 58: 244-258.

http://dx.doi.org/10.1016/j.indcrop.2014.04.022.

13. Nguyen, S. T.; Tran-Le, A. D.; Vu, M. N.; To, Q. D.; Douzane, O.; Langlet, T., 2016: Modeling thermal conductivity of hemp insulation material: A multi-scale homogenization approach. Building and Environment, 107: 127-134. http://dx.doi.org/10.1016/j.buildenv.2016.07.026.

14. Palumbo, M.; Avellaneda, J.; Lacasta, A. M., 2015: Availability of crop by-products in Spain: New raw materials for natural thermal insulation. Resources, Conservation \& Recycling, 99: 1-6. http://dx.doi.org/10.1016/j.resconrec.2015.03.012.

15. Panyakaew, S.; Fotios, S., 2011: New thermal insulation boards made from coconut husk and bagasse. Energy and Buildings, 43: 1732-1739. http://dx.doi.org/10.1016/j.enbuild.2011.03.015.

16. Pásztory, Z.; Mohácsiné, I. R.; Börcsök, Z., 2017: Investigation of thermal insulation panels made of black locust tree bark. Construction and Building Materials, 147: 733735 .

http://dx.doi.org/10.1016/j.conbuildmat.2017.04.204.
17. Schiavoni, S.; D’Alessandro, F.; Bianchi, F.; Asdrubali, F., 2016: Insulation materials for the building sector: A review and comparative analysis. Renewable \& Sustainable Energy Reviews, 62 (C): 988-1011. http://dx.doi.org/10.1016/j.rser.2016.05.045.

18. Sekino, N., 2016: Density dependence in the thermal conductivity of cellulose fiber mats and wood shavings mats: investigation of the apparent thermal conductivity of coarse pores. Journal of Wood Sciences, 62: 20-26. http://dx.doi.org/10.1007/s10086-015-1529-0.

19. Sharma, N.; Sharma, S.; Guleria, S. P.; Batra, N. K., 2015: Mechanical properties of urea formaldehyde resin composites reinforced with bamboo, coconut and glass fibers. International Journal of Soft Computing and Engineering, 5 (2): 66-71.

20. Smulski, S. J.; Ifju, G., 1987: Flexural behavior of glass fiber reinforced hardboard. Wood and Fiber Science, 19 (3): 313-327.

21. Wei, K. C.; Lv, C. L.; Chen, M. Z.; Zhou, X. Y.; Dai, Z. Y.; Shen, D., 2015: Development and performance evaluation of a new thermal insulation material from rice straw using high frequency hot-pressing. Energy and Buildings, 87: 116-122.

http://dx.doi.org/10.1016/j.enbuild.2014.11.026.

22. Yemele, M. C. N.; Blanchet, P.; Cloutier, A.; Koubaa, A., 2008: Effects of bark content and particle geometry on the physical and mechanical properties of particleboard made from black spruce and trembling aspen bark. Forest Products Journal, 58(11): 48-56.

23. Yemele, M. C. N.; Koubaa, A.; Cloutier, A.; Soulounganga, P.; Wolcott, M., 2010: Effect of bark fiber content and size on the mechanical properties of bark/HDPE composites. Composites Part A: Applied Science and Manufacturing, 41 (1): 131-137.

http://dx.doi.org/10.1016/j.compositesa.2009.06.005.

24. Zhou, X. Y.; Zheng, F.; Li, H. G.; Lu, C. L., 2010: An environment-friendly thermal insulation material from cotton stalk fibers. Energy and Buildings, 42: 1070-1074. http://dx.doi.org/10.1016/j.enbuild.2010.01.020.

25. Zolfagari, A.; Behravesh, A. H.; Shahi, P., 2015: Comparison of mechanical properties of wood-plastic composites reinforced with continuous and noncontinuous glass fibers. Journal of Thermoplastic Composite Materials, 28 (6): 791-805. http://dx.doi.org/10.1177/0892705713503676.

26. ***EN 323, 1993: Wood-based panels. Determination of density, 15 April 1993.

27. ***EN 317, 1993: Particleboards and fibreboards. Determination of swelling in thickness after immersion in water, 15 April 1993.

28. ***EN 310, 1993: Wood-based panels. Determination of modulus of elasticity in bending and of bending strength, 15 April 1993.

29. ***EN 319, 1993: Particleboards and fibreboards. Determination of tensile strength perpendicular to the plane of the board, 15 April 1993.

\section{Corresponding address:}

\section{ZOLTAN PÁSZTORY}

University of Sopron

Innovation Center

4 Bajcsy Zs. str. H-9400, Sopron, HUNGARY

e-mail: pasztory.zoltan@uni-sopron.hu 